\title{
Direitos Humanos e Trabalho Escravo Contemporâneo no Brasil
}

Este terceiro número de Brasiliana - Journal for Brazilian Studies tem como tema "Direitos Humanos e Trabalho Escravo Contemporâneo no Brasil". O objetivo deste dossiê foi discutir uma temática sensível e imporante para o Brasil no momento presente.

Desde a promulgação da chamada "Lei Áurea" de 13 de maio de 1888 a escravidão está legalmente abolida no Brasil, no entanto ainda em 2013 subsistem situações nas quais trabalhadores são submetidos em unidades de produção variadas a situações que, pela Código Penal Brasileiro, são reconhecidas como de análoga a de escravo. Em tempos de crescimento econômico, projeção internacional e pretensões de se tornar um "global player", é imprescindível discutir as condições de trabalhadores no Brasil em um contexto de direitos humanos

Os textos que compõem o dossiê publicados neste número da revista contêm parte dos estudos que foram apresentados no decorrer da VI Reunião Científica Trabalho Escravo Contemporâneo e Questões Correlatas entre os dias 29, 30 e 31 de outubro de 2013, na cidade do Rio de Janeiro, no Brasil, promovida pelo Grupo de Pesquisa Trabalho Escravo Contemporâneo que pertence ao Núcleo de Estudos de Políticas Públicas em Direitos Humanos da Universidade Federal do Rio de Janeiro (GPTEC/NEPPDH/UFRJ). O GPTEC, que comemora seu 10 aniversário de existência, realiza as reuniões científicas com profissionais de diversos centros de pesquisa e ensino do Brasil e do exterior. Trata-se de uma material variado, vindo de diversas áreas de conhecimento, de unidades de ensino distintas. Mas com o foco naquilo que no Brasil é conhecido como trabalho análogo a de escravo, como prevê o artigo 149 do Código Penal, ou simplesmente trabalho escravo, como preferem muitos operadores do direito, autoridades do poder executivo e legislativo e grupos de direitos humanos. 
Trata-se de uma produção recente a respeito de estudos elaborados por pesquisadores de campos de saber diferenciados, professores de diversas disciplinas e operadores de direito, inclusive que ocupam cargos públicos importantes na esfera federal. Além dos estudiosos do Brasil e do exterior, há, entre os autores, os agentes sociais que não pertencem aos quadros acadêmicos mas estão ligados à luta cotidiana na área rural, seja como trabalhadores que experimentaram no corpo a ação de proprietários de unidades de produção ou de seus prepostos, seja como lideranças de áreas de fronteira que colocam a vida à disposição de outra his tória, na qual gente não será tratada como se fosse coisa. É um estudo e um grito de alerta a respeito de um problema não suficientemente resolvido: o crime no qual a pessoa não é tratado com dignidade, mas como coisa, objeto.

Na sessão de artigos de temática geral, este número de Brasiliana traz ainda uma série de estudos que abrem reflexões novas sobre temáticas já conhecidas e estudadas no Brasil contemporâneo, bem como análises de aspectos históricos extremamente relevantes para um debate sobre identidade nacional.

Neste terceiro número Brasiliana dá mostras de que caminha a passos firmes e sólidos no caminho de se tornar um canal privilegiado para o debate sobre e com o Brasil.

Agradecemos a todos os que fizeram possível mais este número, em especial aos autores que escolheram Brasiliana para exporem suas pesquisas e a todos os leitores, que fazem na verdade a revista dinâmica e forte. 